Chirurgia (2018) 113: 234-243

No. 2, March - April

Copyright@ Celsius

http://dx.doi.org/10.21614/chirurgia.113.2.234

\title{
Zenker Diverticulum Treatment: Endoscopic or Surgical?
}

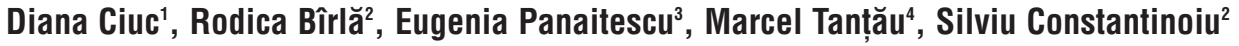 \\ 'ENT Department, CFR 2 Clinic Hospital Bucharest, Romania \\ 2"Carol Davila Bucharest" University of Medicine and Pharmacy, Center of Excellence in Esophageal Surgery, \\ St.Mary Clinical Hospital, Bucharest, Romania \\ ${ }^{3 " C a r o l ~ D a v i l a " ~ U n i v e r s i t y ~ o f ~ M e d i c i n e ~ a n d ~ P h a r m a c y, ~ D e p a r t m e n t ~ o f ~ B i o s t a t i s t i c s ~ a n d ~ M e d i c a l ~ I n f o r m a t i c s, ~ B u c h a r e s t, ~ R o m a n i a ~}$ \\ 4"Iuliu Hatieganu" University of Medicine and Pharmacy, Department of Interventional and Diagnosis Endoscopy, \\ "Prof. Dr. Octavian Fodor" Regional Institut of Hepatology and Gastroenterology, Cluj-Napoca, Romania
}

Corresponding author:

Diana Ciuc, MD

CFR 2 Clinic Hospital Bucharest

E-mail: chirurgie@spcf2.ro

\section{Rezumat}

\section{Tratamentul diverticulului Zenker: endoscopic sau chirurgical?}

Introducere: Diverticulul Zenker constituie o patologie rară, selecția pacienților pentru tratamente invazive este discutabilă, precum şi metoda terapeutică aplicată. Scopul studiului este de a evalua principalele metode de tratament-chirurgical clasic si endoscopic, în această patologie şi de a corela aspectele fiziopatologice cu consecințele clinice.

Material şi metodă: Am inclus în lotul de studiu 36 pacienți cu diverticuli cervicali Zenker tratați în perioada 2010/2017 în două clinici universitare: 7 pacienți prin abord chirurgical clasic la Clinica de Chirurgie Generală şi Esofagiană a Spitalului Clinic Sfânta Maria Bucureşti şi 29 de pacienți cu abord endoscopic la Departamentul de Endoscopie Digestivă de Diagnostic şi Intervențională din cadrul Institutului Regional de Hepatologie şi Gastroenterologie Prof. Dr. Octavian Fodor, Cluj-Napoca. Vârsta pacienților a fost cuprinsă între 42 şi 84 ani şi în decada a 7 a - 15 pacienți.

Rezultate: Miotomia cricofaringiană s-a efectuat la toți pacienții. Diverticulectomia s-a practicat la 7 pacienți, cei tratați chirurgical. Durata de spitalizare medie a fost de 4 zile. Complicații intraprocedurale au prezentat 3 pacienți tratați endoscopic şi au constat în apariția hemoragiei laminare. La 2 pacienți s-a practicat hemostază endoscopică cu clipuri şi pensă caldă iar la un pacient s-a efectuat hemostază endoscopică cu clipuri. Complicațiile postprocedurale au fost: dureri locale, leucocitoză, melenă, febră, 
hematom cervical. Aceste manifestări postprocedurale au fost întâlnite la 6 pacienți. Morbiditatea postprocedurală a fost $16,66 \%$.

Concluzii: La pacienții incluşi în lot, eficiența tratamentului endoscopic a fost de 80\%. simptomatologia postintervențională persistentă a fost reprezentată în principal de disfagie; sialoreea postprocedurală s-a asociat cu persistența disfagiei. Pacienții cu simptomatologie postprocedurală persistentă au necesitat reintervenție.

Cuvinte cheie: diverticul Zenker, tratament endoscopic, diverticulectomie, miotomie cricofaringiană

\begin{abstract}
Introduction: The Zenker Diverticulum is a rare pathology, the selection of patients for invasive treatments is questionable, as well as the applied therapeutic method. The aim of the study is to evaluate the main methods of classical and endoscopic surgical treatment in this pathology and to correlate pathophysiological aspects with clinical consequences.

Material and method: We included 36 patients with Zenker hypopharyngeal diverticulum treated in 2010/2017 in two university clinics: 7 patients by classical surgical approach at the General and Esophageal Surgery Clinic of St. Mary's Hospital Bucharest and 29 patients with endoscopic approach at Department of Diagnostic and Interventional Digestive Endoscopy of the Regional Institute of Hepatology and Gastroenterology Prof Dr Octavian Fodor, Cluj-Napoca. The age of the patients ranged from 42 to 84 years and in the 7 th to 15 th decade.

Results: Cricopharyngeal myotomy was performed in all patients. Diverticullectomy was performed in 7 patients treated surgically. The average hospitalization duration was 4 days. Intra-procedural complications showed 3 patients treated endoscopically and consisted of laminar haemorrhage. Two patients were treated with endoscopic endoscopic hemostasis and hot pens and one patient had endoscopic hemostasis with clips. The post-procedural complications were: local pain, leukocytosis, melena, fever, cervical hematoma. These post-treatment events were seen in 6 patients. The posttreatment morbidity was $16.66 \%$.

Conclusions: In patients included in the batch, the endoscopic treatment efficiency was $80 \%$. Peristent postinterventional symptomatology was mainly represented by dysphagia, post-procedural syndrome was associated with dysphagia persistence. Patients with persistent post-surgical symptoms were required to reintervention.
\end{abstract}

Key words: Zenker diverticulum, endoscopic treatment, diverticullectomy, cricopharyngeal myotomy

\section{Introduction}

The Zenker Diverticulum (DZ), also known as the hypopharyngeal diverticulum, is a mucosal and submucosal sac-shaped sac that originates in the pharyngoesophageal junction. DZ is located on the dorsal side of the pharyngoesophageal wall by Killian's dehiscence and is bounded by the inferior pharyngeal constrictor muscle and the cross-hair fibers of the cricopharyngeal muscle (contributing to the upper esophageal sphincter) (1) Typical symptoms are dysphagia, regurgitation, chronic cough, aspiration, and weight loss. The exact etiology remains unclear, the most accepted theory being the disturbance of the pharyngeal-esophageal motility. (2) Currently, the therapeutic attitude varies between conservative and surgical, classical or endoscopic treatment. Treatment should be reserved for symptomatic patients with or without associated complications $(3,4)$, while small, asymptomatic diverticula do not 
require treatment, as the risk of severe adverse events (cancer, aspiration pneumonia) is reduced (5). The surgical indication, as expressed in the literature, is still vaguely specified, varies between the formal indication for surgery, determined by the simple presence of the diverticular sac at the pharyngoesophageal level, up to a case-adjusted attitude depending on the presence of the symptomatology specific age, associated illness and of course the installation of direct complications, an attitude we opt for.

\section{Material and Method}

We included 36 patients with cervical diverticulum Zenker treated in 2010/2017 in two university clinics: the General and Esophageal Surgery Clinic of St. Mary's Hospital Bucharest and the Department of Diagnostic and Interventional Digestive Endoscopy of the Regional Hepatology Institute and Gastroenterology Prof Dr Octavian Fodor, ClujNapoca. Batch inclusion criteria: Patients with Zenker diverticals enrolled and treated endoscopically or surgically in the hospital during 2010/2017, over 18 years of age, patients investigated imaging with barium transit and endoscopy, patients with a follow-up period of 12 months postprocedural. Exclusion criteria: immunosuppressed patients, patients with associated malignancy, patients lost from posttracing follow-up. The distribution of patients by gender was relatively equal - F / M- 15 / 21 . Most of the patients included in the study are in the 7th decade of life. Patients included in the batch presented co-morbidities. Nearly a quarter of patients had no comorbidities, and only one patient had a combination of 4 comor- $^{-}$ bidities: atrial fibrillation, HTAE, coronary ischemic disease and sigmoid diverticulosis. Upon admission, the patients included in the study exhibited both esophageal symptoms: dysphagia, pyrosis, sialorrhea, and extraesophagitis: dysphonia, odinophagia, cough. Most patients accused 3 symptoms - 41.7\%. Dysphagia has been a constant symptom in hospital presentation. The evaluation of this symptom was made after the Mellow-Pinkas proposed dysphagia depending on the type of food that can not be swallowed - Grade 0 - No Dysphagia, Grade 1 - Dysphagia for Solids, Grade 2 - Dysphagia for Semisolid, Grade 3 Dysphagia for solid and liquid grade 4 - Total dysphagia (inability to swallow saliva). In the study group, $55.6 \%$ of patients had grade 2 dysphagia. Symptomatology in the ENT sphere was present in 10 of the 36 patients in the study and consisted of dysphonia, cough, odinophagia and was associated with oesophageal manifestations $70 \%$ of patients. All of the patients included in the group performed imaging experiments: X-ray examination with barium and EDS. EDS highlights the presence of the diverticulum, the diverticulum ventricular opening dimensions, the diverticulum content of the diverticulum and the diverticulary mucosal appearance sometimes with diverticulitis aspect (Figs. 1, 2).

Barium X-ray examination gives information about the true size of the diverticulum, its content, possibly an associated pathology (Figs. 3, 4)

Exploration of oesophageal motility was done by means of oesophageal manometry. In patients in the batch, I did not experience manometric changes of the inferior esophageal sphincter in terms of its positioning, volume vector or relaxation but only changes in motility in the sense of reduced amplitude and aperistaltic contraction waves (Fig. 5).

The diverticular dimensions were appreciated both in centimeters and degrees depending on the Overbeeck classification by corroborating the data obtained from the endoscopic exploration and baritone transit aspect. Most of the patients had grade 1 and 2 diverticula, only 4 patients had grade 3 diverticulum. Secondary diarticulosis of the food stool of the retentive diverticula was present in only 9 patients. Patients who did not have diverticulitis had mainly small diverticulitis - 14 grade 1 diverticulitis patients and 13 grade 2 diverticulitis patients.

\section{Results}

All 36 patients in the study group underwent an endoscopic or surgical therapy procedure. 


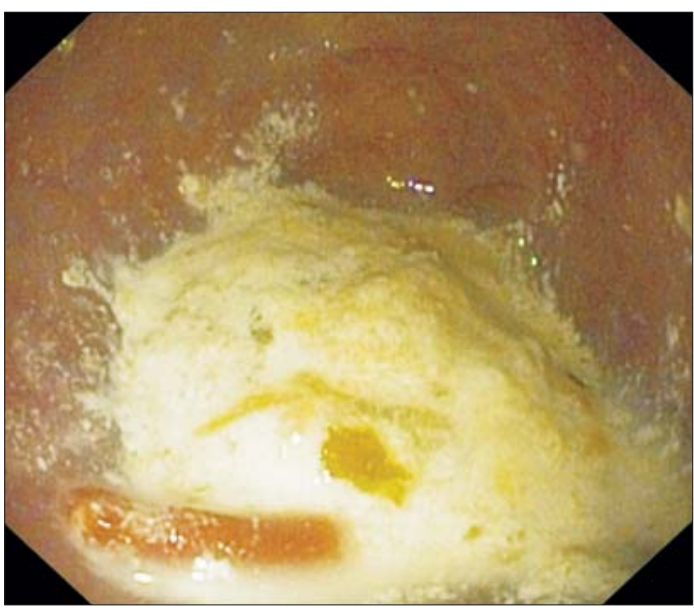

Figure 1. Endoscopic aspect of the diverticular pouch- food and barium residues

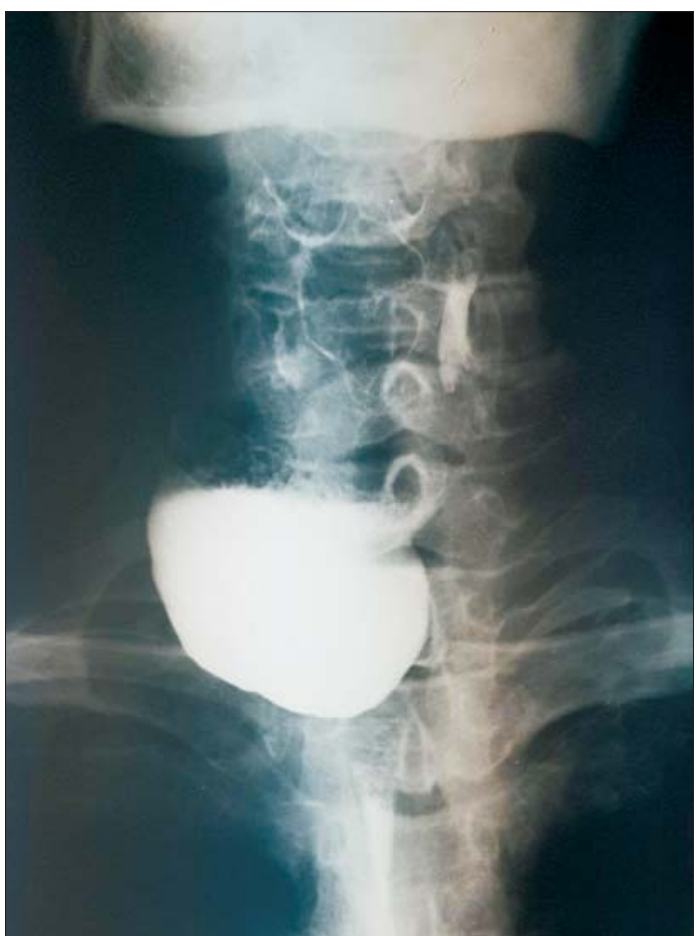

Figure 3. Barium X-ray examination - front view voluminous plugs retracted retosternal

29 patients were treated endoscopically by myotomy in the Department of Diagnostic and Interventional Digestive Endoscopy of the Regional Institute of Hepatology and Gastroenterology Prof Dr Octavian Fodor, Cluj-Napoca and 7 patients were surgically treated by the resection of diverticulature associated with myotomy in the Clinic of

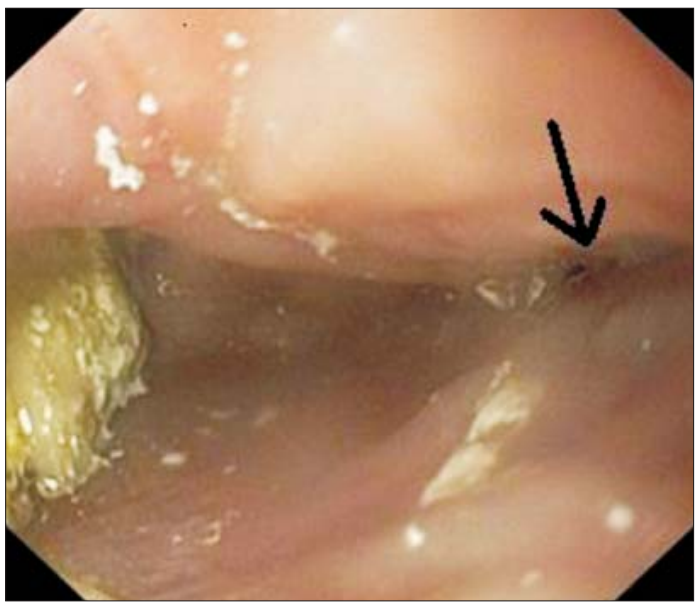

Figure 2. Endoscopic appearance of the esophagus opening with Zenker diverticula (arrowhead)

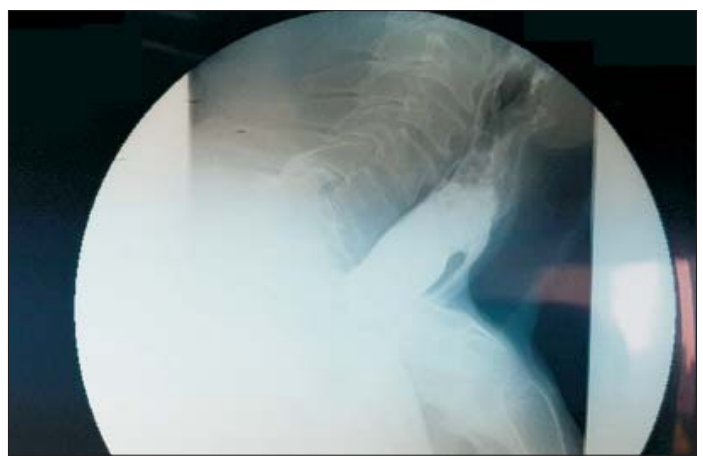

Figure 4. Zenker diverticulum- lateral view - cervical esophagus compressed by a voluminous Zenker diverticulum

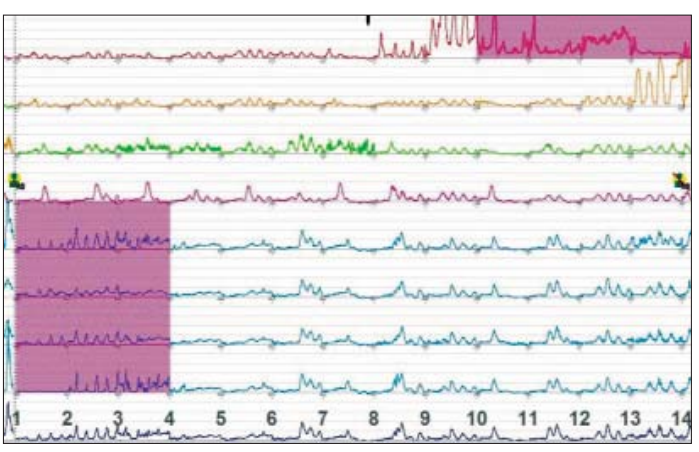

Figure 5. Conventional esophageal manometry - an ineffective esophageal motility aspect in a Zenker diverticulum patient

General and Esophageal Surgery of St. Mary's Hospital Bucharest. Endoscopic surgery was performed with the creation of a broad communication of the diverticulus with the esophagus without the resection of the 


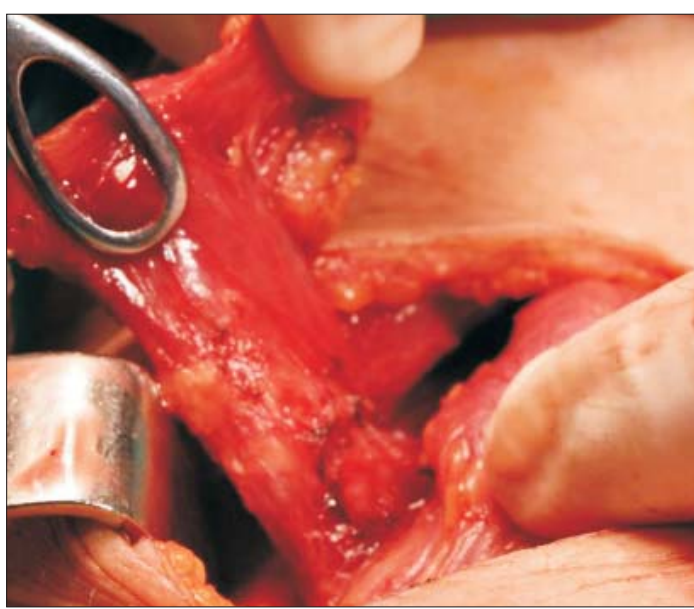

Figure 6. Intraoperative aspect - Zenker diverticulum dissected and externalized through the leftâ cervicotomy incision

diverticular pouch, and the resection of the diverticulum with myotomy and the esophageal manually sutured suture or double layer or mechanical using the stapler was performed surgically by cervicotomy (Figs. 6, 7, 8).

Intra-procedural complications presented 3 patients treated endoscopically and consisted of laminar haemorrhage. In 2 patients, endoscopic hemostasis was performed with clips and hot pens and a patient had endoscopic hemostasis with clips. The post-procedural complications were: local pain, leukocytosis, melena, fever, cervical hematoma. These post-treatment events were seen in 6 patients. The post-treatment morbidity was $16.66 \%$.

\section{Statistical Analysis}

By correlating the post-procedural complications with the sex of the patients, the presence of the comorbidities, the presentation symptoms, the size of the diverticles expressed in centimeters or in degrees, the type of intervention, the practice

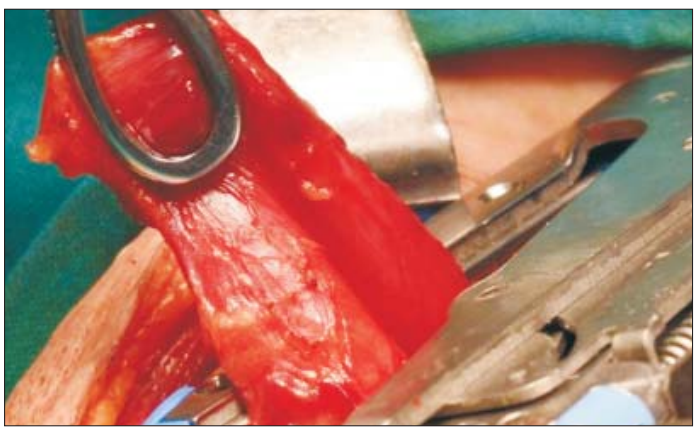

Figure 7. Intraoperative aspect - application of the linear stapler at the base of the Zenker diverticulum

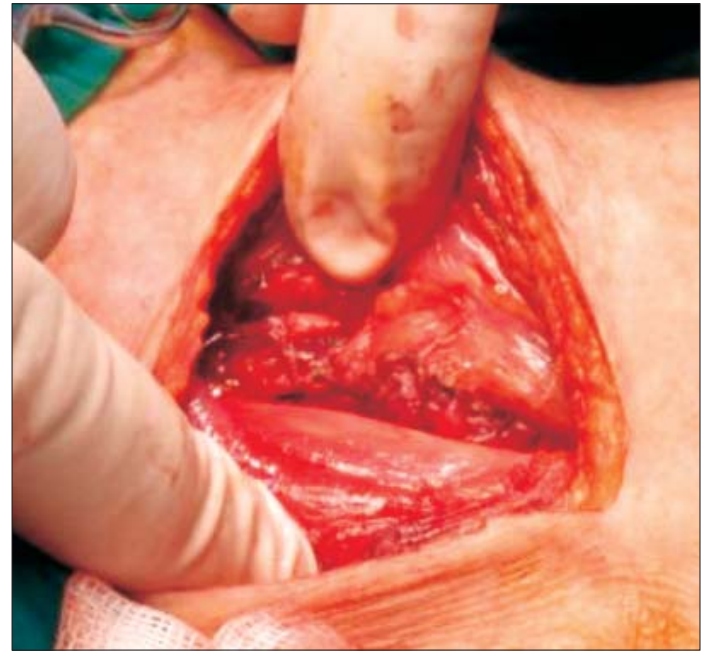

Figure 8. Intraoperative aspect - final appearance after Zenker diverticulum resection and additional manual suturing after application of the stapler

of the myotomy or the diverticular resection and the procedural intra-procedural complications, we did not find statistically significant values. A significant difference is observed between hospitalizations in post-treatment complications and those without post-procedural complications ( $p \_$value $=0.007081$, Mann-Whitney Test) (Table 1).

Table 1. Correlation of post-procedural complications with the duration of hospitalization - statistical data processing

\begin{tabular}{lll}
\hline $\begin{array}{l}\text { Postprocedural complications }=\text { Yes } \\
\mathbf{( N = 6 )}\end{array}$ & $\begin{array}{l}\text { Postprocedural complications }=\mathbf{N} \\
\mathbf{( N = 3 0 )}\end{array}$ & P_value (test) \\
\hline $8.67 \pm 6.4083$ & $3.17 \pm 2.6403$ & 0.007081 \\
$7.00(3.50,15.00)$ & $2.00(2.00,3.00)$ & (Mann-Whitney Test) \\
\hline
\end{tabular}


On average, patients with no postprocedural morbidity necessitated a 2-days hospitalization period, whereas patients with postprocedural morbidity necessitated a 7-days hospitalization period.

Persistent postprocedural symptomatology was present for 11 patients and consisted in persistency of a lower degree dysphagia which might be associated to other symptoms (sialorrhea, regurgitations, nausea, cough).

No statistically significant differences were noticed with regard to postprocedural sympotomatology in correlation to sex and initial symptomatology. Yet, significant difference in terms of hospitalization duration was noticed between patients with and without post-interventional sympotomatology. (p_value = 0.005955, Mann-Whitney Test) (Table 2).

Postprocedural symptomatology was observed at 5 out of 29 endoscopically treated patients, and at 6 out of 7 who underwent surgery (Table 3).

Postprocedural persistent symptoms may be influenced by used technique (i.e., diverticular poach resection or lack of resection, presence or absence of myotomy). For patients in the test lot, diverticulum resection was carried out only for surgically treated patients (Table 4).

Out of 11 patients with postinterventional symptomatology, 4 had degree-3 diverticulum.

Table 2. Correlation of postinterventional symptomatology with hospitalization duration - statistical data processing

\begin{tabular}{llll}
\hline & $\begin{array}{l}\text { Postinterventional } \\
\text { symptomatology }=\text { Yes } \\
(\mathbf{N}=11)\end{array}$ & $\begin{array}{l}\text { Postinterventional } \\
\text { symptomatology = No } \\
(\mathbf{N}=\mathbf{2 5})\end{array}$ & P_value (test) \\
\hline Hospitalization duration & $7.55 \pm 5.5563$ & $2.56 \pm 1.5832$ & 0.005955 \\
& $8.00(2.00,11.00)$ & $2.00(2.00,3.00)$ & (Mann-Whitney Test) \\
\hline
\end{tabular}

Table 3. Corrlation of postinterventional symptomatology with procedure - statistical data processing

\begin{tabular}{llll}
\hline & $\begin{array}{l}\text { Postinterventional } \\
\text { symptomatology =Yes } \\
(\mathbf{N}=\mathbf{1 1})\end{array}$ & $\begin{array}{l}\text { Postinterventional } \\
\text { symptomatology = No } \\
(\mathbf{N}=\mathbf{2 5})\end{array}$ & P_value (test) \\
\hline $\begin{array}{l}\text { Intervention surgery } \\
\text { endoscopical }\end{array}$ & $6 / 11(54.5 \%)$ & $1 / 25(4.0 \%)$ & 0.001423 \\
\hline Myotomy=Yes & $5 / 11(45.5 \%)$ & $24 / 25(96.0 \%)$ & (Fisher's Exact Test) \\
\hline & $11 / 11(100 \%)$ & $24 / 25(96.0 \%)$ & 1.000000 \\
& & & (Fisher's Exact Test) \\
\hline
\end{tabular}

significant differences were noticed between the type of intervention (surgery or endoscopic) ( $p \_v a l u e=0.001423$, Fisher's Exact Test) and the persistency of postinterventional sympoto-matology (endoscopic treatment $=45.5 \%$ ) and those without postinterventional symptomato-logy (endoscopic treatment $=96.0 \%$ ) $-96 \%$ of patients with no postinterventional symptomatology underwent endoscopic treatment

Table 4. Correlation of posyinterventional symptomatology with diverticulum resection - statistical data processing

\begin{tabular}{llll}
\hline & $\begin{array}{l}\text { Postinterventional } \\
\text { symptomatology =Yes } \\
(\mathrm{N}=11)\end{array}$ & $\begin{array}{l}\text { Postinterventional } \\
\text { symptomatology = No } \\
(\mathrm{N}=25)\end{array}$ & P_value (test) \\
\hline Resection $=\mathrm{Da}$ & $6 / 11(54.5 \%)$ & $1 / 25(4.0 \%)$ & 0.001423 \\
& & & (Fisher's Exact Test)
\end{tabular}

significant difference was observed in regard to percentage of resected diverticula between patients with postinterventional persistent symptomatology $(54.5 \%)$ and patients with no postinterventional persistent symptomatology $(4.0 \%)$ ( $p \_$value $=0.001423$, Fisher's Exact Test) - presence of symptoms was predominantly noticed at patients having underwent resection 
Table 5. Correlation of posyinterventional symptomatology with dimension of diverticulum (cm) and of degrees of diverticulitis - statistical data processing

\begin{tabular}{|c|c|c|c|}
\hline & $\begin{array}{l}\text { Postinterventional } \\
\text { symptomatology }=\text { Yes } \\
(\mathrm{N}=11)\end{array}$ & $\begin{array}{l}\text { Postinterventional } \\
\text { symptomatology = No } \\
(\mathrm{N}=25)\end{array}$ & P_value (test) \\
\hline Dimension & $\begin{array}{l}4.00 \pm 1.7320 \\
4.00(3.00,5.00)\end{array}$ & $\begin{array}{l}2.72 \pm 0.7916 \\
3.00(2.00,3.00)\end{array}$ & $\begin{array}{l}0.014844 \\
\text { (Mann-Whitney Test) }\end{array}$ \\
\hline Dimension classification & & & $\begin{array}{l}0.003085 \\
\text { (Likelihood Ratio) }\end{array}$ \\
\hline 1 & 2/11 (18.2\%) & $12 / 25(48.0 \%)$ & \\
\hline 2 & $5 / 11(45.5 \%)$ & $13 / 25(52.3 \%)$ & \\
\hline 3 & $4 / 11(36.4 \%)$ & $0 / 25(0.0 \%)$ & \\
\hline Diverticulitis $=$ Yes & $4 / 11(36.4 \%)$ & $5 / 25(20.0 \%)$ & $\begin{array}{l}0.408774 \\
\text { (Fisher's Exact Test) }\end{array}$ \\
\hline
\end{tabular}

Correlation of diverticulum dimension (as a function of degree) with postprocedural symptomtology persistence has determined statistically significant difference $\left(p \_v a l u e=\right.$ 0.014844, Mann-Whitney Test) both in what concerns dimension (expressed in $\mathrm{cm}$ ) and values expressed in degrees (as per Overbeeck classification) (Table 5).

Diverticula up to $3 \mathrm{~cm}$ seldom led to postprocedural symptoms, whereas diverticula larger than $4 \mathrm{~cm}$ were more susceptible for persistency of postprocedural symptoms.

The significant difference was noticed 'by correlating the percentage of patients with diverticulum of degree 3 and the persistency of postinterventional symptomatology ( $\mathrm{p}$ _value $=$ 0.003085, Likelihood Ratio), namely: between patients with postinterventional symptomatology $(36.4 \%)$ and those without postinterventional symptomatology $(0.0 \%)$ voluminous diverticula chiefly made the difference between patients with or without persisting postprocedural symptomatology.
In the context of postprocedural symptomatology, dysphagia was the key symptom (10 out of 11 patients): 4 patients had score 1 dysphagia, whereas 6 patients had score 2 dysphagia (Table 6).

Persistent postprocedural dysphagia was present in 11 patients - 5 of which underwent surgery, and 6 endoscopic treatment (Table 7).

Endoscopic treatment was beneficial for $80 \%$ of patients who underwent this type of procedure (Table 8).

10 out of 11 patients with postinterventional symptomatology have presented persistence of dysphagia with a lower score than initially.

Distribution of patients with persistent dysphagia with type of intervention. Postprocedural sialhorrea was noticed in 4 patients, not as unique symptom, but always in association with dysphagia (Table 9).

Reintervention was deemed necessary for 7 out of 11 patients with persistent postprocedural symptoms (Table 10).

Table 6. Correlation of postinterventional symptomatology with persistent dysphagia - statistical data processing

\begin{tabular}{llll}
\hline & $\begin{array}{l}\text { Postinterventional } \\
\text { symptomatology =Yes } \\
(\mathrm{N}=11)\end{array}$ & $\begin{array}{l}\text { Postinterventional } \\
\text { symptomatology }=\text { No } \\
(\mathrm{N}=\mathbf{2 5})\end{array}$ & P_value (test) \\
\hline Dysphagia=Yes & $10 / 11(90.9 \%)$ & $1 / 25(4.0 \%)$ & 0.000000 \\
& & (Fisher's Exact Test) \\
\hline
\end{tabular}

significant difference was noticed in regard of presence of dysphagia ( $\mathrm{p}$ _value $=0.000000$, Fisher's Exact Test) between patients with postinterventional symptomatology $(90.9 \%)$ and those without $(4.0 \%)$. Actually, persistent postinterventional symptomatology was mainly characterized by dysphagia 
Table 7. Correlation of type of intervention with postprocedural persistence dysphagia - statistical data processing

\begin{tabular}{llll}
\hline & intervention=S $\mathbf{( N = 7 )}$ & intervention=E $(\mathbf{N}=29)$ & $\mathbf{P}$ _value (test) \\
\hline Score of dysphagia & & 0.027866 \\
& & & \\
0 & $2 / 7(28.6 \%)$ & $23 / 29(79.3 \%)$ & \\
1 & $3 / 7(42.9 \%)$ & $2 / 29(6.9 \%)$ & \\
2 & $2 / 7(28.6 \%)$ & $4 / 29(13.8 \%)$ & \\
\hline Persistent Dyspahia significantly differs with the type of intervention (p_value $=0.027866$ Likelihood Ratio) &
\end{tabular}

Table 8.

\begin{tabular}{lll}
\hline & $\begin{array}{l}\text { Postinterventional symptomatology }=\text { Yes } \\
(\mathbf{N}=11)\end{array}$ & $\begin{array}{l}\text { Postinterventional symptomatology = No } \\
(\mathbf{N}=25)\end{array}$ \\
\hline Score of dysphagia & & \\
0 & $1 / 11(9.1 \%)$ & $24 / 25(96.0 \%)$ \\
1 & $4 / 11(36.4 \%)$ & $1 / 25(4.0 \%)$ \\
2 & $6 / 11(54.5 \%)$ & $0 / 25(0.0 \%)$ \\
\hline
\end{tabular}

Table 9.

\begin{tabular}{llll}
\hline & $\begin{array}{l}\text { Postinterventional } \\
\text { symptomatology }=\text { Yes } \\
(\mathbf{N}=11)\end{array}$ & $\begin{array}{l}\text { Postinterventional } \\
\text { symptomatology = No } \\
(\mathbf{N}=\mathbf{2 5})\end{array}$ & P_value (test) \\
\hline sialorrhea $=$ Yes & $4 / 11(36.4 \%)$ & $0 / 25(0.0 \%)$ & $\begin{array}{l}0.005602 \\
\text { (Fisher's Exact Test) }\end{array}$ \\
\hline
\end{tabular}

sialorrhea persisted postprocedurally in 4 patients, which led to significant difference as regards this symptom between patients with postprocedural symptomatology $(36.4 \%)$ and those without $(0.0 \%)$. ( $p \_$value $=0.005602$, Fisher's Exact Test)

\section{Discussions}

Zenker Diverticulum or pharyngeal pouch is an anatomic defect characterized by herniation of the posterior pharyngeal wall and can lead to dysphagia and regurgitation.

Symptomatic Zenker diverticulum therapy has evolved from a open surgical approach to minimally invasive transoral endoscopic techniques. Transoral endoscopic therapy using rigid instruments is performed primarily by otorhinolaryngologists, while transoral therapy using flexible endoscopes is performed by endoscopic surgeons and gastroenterologists.

The common purpose of all the modalities is the dismantling of the septum between the esophageal lumen and the septal diverticulum containing the cricopharyngeal muscle (7).

Table 10. Correlation of postinterventional symptomtology with reintervention - statistical data processing

\begin{tabular}{|c|c|c|c|}
\hline & $\begin{array}{l}\text { Postinterventional } \\
\text { symptomatology =Yes } \\
(\mathrm{N}=11)\end{array}$ & $\begin{array}{l}\text { Postinterventional } \\
\text { symptomatology = No } \\
(\mathrm{N}=25)\end{array}$ & P_value (test) \\
\hline Reintervention $=$ Yes & $7 / 11(63.6 \%)$ & $0 / 25(0.0 \%)$ & $\begin{array}{l}0.000040 \\
\text { (Fisher's Exact Test) }\end{array}$ \\
\hline
\end{tabular}


Compliance of the upper esophageal sphincter is affected in Zenker diverticulum patients and is normalized by surgery. This physiopathological principle argues that cricopharyngeal myotomy is a mandatory component of Zenker diverticulum surgery. This principle is met both by the surgical, traditional approach and by the modern endoscopic approach (8).

The selection of patients for the application of a particular type of therapy has not been standardized, as commonly found in literature data, possibly due to the reduced incidence of this disorder. Usually, elderly patients tended to be treated with an endoscopic approach, with lower rates of complications and a shorter stay in the hospital. since patients with Zenker diverticulum usually have many comorbidities, their clinical condition is essential to select the best treatment. Also, doctors' preferences, training, and practice standards are important issues in the final decision. Last but not least, the wishes of the patient should be considered (9).

Randomized studies are missing and the treatment method is usually chosen based on personal experience or preference. Although the overall tendency is to flexible endoscopic procedures, open surgery remains an alternative if endoscopic procedures fail. A major advantage of flexible endoscopic treatment, in addition to the $15 \%$ low complication rate and $0 \%$ mortality, is that it can be performed under conscious sedation compared to open surgery or rigid endoscopy.

The follow-up of patients was performed by anamnesis, clinical examination, imaging investigations. The clinical criteria followed were: persistence or recurrence of dysphagia and regurgitation as in other similar studies.

In patients in the study we had an average hospital stay of 4 days, the average hospitalization after endoscopic treatment was 2.3 days and 11.4 days after surgical treatment. similar data were reported by other authors who observed an hospital stay between 2, 24 and 5 days $(12,13)$

Although surgical intervention requires a longer time both as operator time and as days of hospitalization versus the endoscopic approach suggested by other studies, (11).

There was no mortality related to the procedure, issues encountered in other studies, but we noticed complications in 6 patients / $16.6 \%$ compared to $17.6 \%$ reported by other studies. In the patients group we recorded intraoperative complications in 3 endoscopically operated patients - $8.3 \%$ comparable to $6.8 \%$ reported by other studies. Only $2.6 \%$ of patients reported postoperative complications. Endoscopic first-line treatment had a success rate of $80 \%$ comparable to those in literature where comparable success rates are reported and may reach a $95.5 \%$ success rate after reintervention for the incomplete septum section. (14) Other authors report initial relief of recurrent symptoms in $90.2 \%$ of patients after a single procedure. (15) The rate of recurrent symptoms was significantly higher in the surgical group than in the endoscopic group - $17.24 \%$ results different from those reported in other studies where a recurrence rate of $39 \%$ was found after endoscopic treatment and $0 \%$ recurrence in the group patients who underwent surgery. (11)

The higher rate after flexible endoscopic treatment could be caused by incomplete septal dissection. Some authors have shown that treatment success correlates with the length of septotomy. The risk of perforation by imprecise sectioning and the difficulty of identifying the last cricopharyngeal fibers could cause the endoscopist to retain a residual part of the septum to avoid penetration into the mediastinal space(10).

The persistence of symptomatology occurred in 11 patients, 5 patients after endoscopic treatment against some literature data showing recurrence of $12.8 \%$. Most patients whose recurrence fails the procedure have undergone all endoscopic reintervention similar to other data published in the literature. (15)

Patients in the study who experienced postprocedural complications required significantly more statistically significant hospitalization. similar data reported by other authors (16). 


\section{Conclusions}

1. The length of hospitalization was higher in patients with post-procedural complications, post-interventional symptomatology and those treated surgically.

2. In patients included in the batch, the endoscopic treatment efficiency was $80 \%$.

3. Persistent postinterventional symptomatology was mainly represented by dysphagia, post-procedural sialorrhea was associated with persistent dysphagia.

4. Diverticles of grade III or sizes larger than $4 \mathrm{~cm}$ were more susceptible to postprocedural persistence of symptomatology. 5. Patients with persistent post-surgical symptoms were required to reintervention.

\section{Acknowledgements}

We particularly thank the Professor of Polytechnic University of Bucharest Deparment of Applied Electronics and Information Engineering Mr. Ciuc Mihai for significant contribution to writing the article and Assistant Professor Mr. Hoara Petre for friendly support in providing the upper endoscopy images and esophageal manometry.

\section{Conflict of Interest}

The authoirs declare that they have no conflict of interest.

\section{Ethical Approval}

Informed consent was obtained from all patients for being included in the study.

\section{References}

1. Cook IJ, Gabb M, Panagopoulos V, Jamieson GG, Dodds WJ, Dent $J$, Shearman DJ. Pharyngeal (Zenker's) diverticulum is a disorder of upper esophageal sphincter opening. Gastroenterology. 1992;
103(4):1229-35.

2. Constantinoiu S, Constantin A, Achim F. În: Constantinoiu S, editor. Tratat de patologie si chirurgie esofagiana. Chapter 9 - Tulburari de motilitate esofagiana. Bucuresti: Editura Academiei Romane. 2017. p. 349-363

3. Ferreira LE, simmons DT, Baron TH. Zenker's diverticula: pathophysiology, clinical presentation, and flexible endoscopic management. Dis Esophagus. 2008:21(1):1-8. doi: 10.1111/j.1442-2050.2007.00795.x.

4. Dzeletovic I, Ekbom DC, Baron TH. Flexible endoscopic and surgical management of Zenker's diverticulum. Expert Rev Gastroenterol Hepatol. 2012;6(4):449-65; quiz 466. doi: 10.1586/ egh.12.25.

5. Herbella FA, Patti MG. Modern pathophysiology and treatment of esophageal diverticula. Langenbecks Arch Surg. 2012;397(1):2935. doi: 10.1007/s00423-011-0843-2. Epub 2011 Sep 2.

6. Ishaq S, Sultan H, Siau K, Kuwai T, Mulder CJ, Neumann H. New and emerging techniques for endoscopic treatment of Zenker's diverticulum: State-of-the-art review. Dig Endosc. 2018 Feb 9. doi: 10.1111/den.13035. [Epub ahead of print]

7. Law R, Katzka DA, Baron TH. Zenker's Diverticulum. Clin Gastroenterol Hepatol. 2014:12(11):1773-82; quiz e111-2. doi: 10.1016/j.cgh. 2013.09.016. Epub 2013 Sep 18.

8. Shaw DW, Cook IJ, Jamieson GG, Gabb M, Simula ME, Dent J. Influence of surgery on deglutitive upper oesophageal sphincter mechanics in Zenker's diverticulum. Gut. 1996;38(6):806-11.

9. Albers DV, Kondo A, Bernardo WM, Sakai P, Moura RN, Silva GL, et al. Endoscopic versus surgical approach in the treatment of Zenker's diverticulum: systematic review and meta-analysis. Endosc Int Open. 2016;4(6):E678-86. doi: 10.1055/s-0042106203. Epub 2016 May 10.

10. Wilmsen J, Baumbach R, Stüker D, Weingart V, Neser F, Gölder SK, et al. New flexible endoscopic controlled stapler technique for the treatment of Zenker's diverticulum: A case series. World J Gastroenterol. 2017;23(17):3084-3091. doi: 10.3748/wjg.v23.i17.3084.

11. Shahawy S, Janisiewicz AM, Annino D, Shapiro J. A comparative study of outcomes for endoscopic diverticulotomy versus external diverticulectomy. Otolaryngol Head Neck Surg. 2014;151(4):646-51. doi: 10.1177/0194599814541920. Epub 2014 Jul 2.

12. Dișibeyaz S, Kuzu UB, Parlak E, Saygili F, Öztas E, Ari D, et al. Endoscopic Treatment of the Zenker Diverticulum With Flexible Endoscopic Myotomy: A single Tertiary Center Experience. Surg Laparosc Endosc Percutan Tech. 2017;27(6):e136-e140. doi: 10.1097/SLE.0000000000000475.

13. Wasserzug 0, Zikk D, Raziel A, Cavel 0, Fleece D, Szold A. Endoscopically stapled diverticulostomy for Zenker's diverticulum: results of a multidisciplinary team approach. Surg Endosc. 2010; 24(3):637-41. doi: 10.1007/s00464-009-0651-8. Epub 2009 Aug 18.

14. Mazza M, Bergamini AN, Parise P, Cossu A, Adamenko 0, Elmore $\mathrm{U}$, et al. Treatment of Zenker's Diverticulum With Endoscopic Stapled Esophago-divertisculostomy (ESD): Analysis of Long-term Outcome. Surg Laparosc Endosc Percutan Tech. 2017;27(6):445448. doi: $10.1097 /$ SLE.0000000000000473.

15. Aiolfi A, Scolari F, Saino G, Bonavina L. Current status of minimally invasive endoscopic management for Zenker diverticulum. World J Gastrointest Endosc. 2015;7(2):87-93. doi: 10.4253/wjge.v7.i2.87.

16. Khetani JD, Janjua A, Fenton RS. Staple-assisted endoscopic management of Zenker's diverticula: a role in the geriatric population. Indian J Otolaryngol Head Neck Surg. 2009:61(3):200-4. doi: 10.1007/s12070-009-0066-9. Epub 2009 Sep 27. 